\title{
CDH1 Gene Promoter Hypermethylation
}

National Cancer Institute

\section{Source}

National Cancer Institute. CDH1 Gene Promoter Hypermethylation. NCI Thesaurus.

Code C158106.

A genetic finding indicating an excess of DNA methylation in the promoter region of the $\mathrm{CDH} 1$ gene. 